Вісник Львівського університету. Серія філос.-політолог. студіі. 2020. Випуск 30, с. 116-124

Visnuk of the Lviv University. Series Philos.-Political Studies. Issue 30, p. 116-124

UDC 2-81-587.6

DOI https://doi.org/10.30970/PPS.2020.30.16

\title{
FEATURES OF THE FORMATION OF THE VIRGIN DOGMATS IN CATHOLICISM
}

\author{
Galyna Rozbytska \\ Ivan Franko Zhytomyr State University, \\ Department of Philosophy and Political Science \\ Velyka Berdychivska str., 40, 10008, Zhytomyr, Ukraine
}

The article analyzes the formation of the cult of the Mother of God in Christianity. It is proved that the formation of the cult of the Virgin Mary took place during the Ecumenical Councils, which laid the fundamental foundations of Christianity in Trinitarian teaching, Christological theology and Mariology. It is substantiated that the Second Ecumenical (First Constantinople) Council, asserting the substantial identity of the Persons of the Trinity, could not put an end to Christological discussions on the question of the union of the divine and human nature of Christ, which remained open.

The main dogmatic dogmas in Catholicism are singled out, which complement the Christological doctrine formed on the basis of the New Testament literature. The sources of formation of ideas about the Blessed Virgin, which belong to the period of early Christianity, are determined. The significance of the Council of Ephesus was established, which laid the foundation for the veneration of the Virgin Mary, proclaiming her the Mother of God. The superiority in the Christological debates of Alexandrian catechetical theology over the Antiochian theological school is proved. Conclusions are formulated, and the theoretical provisions concerning the cult of the Blessed Virgin Mary are generalized by studying historical materials and modern developments in the field of theology and in the field of philosophical sciences. It is substantiated that the Christological conception of the Patriarch of Constantinople Nestorius led to the recognition of two incarnations in Christ and the denial of ontological unity. For Nestorius, both incarnations of Christ are original, independently existing, because each of them forms a Person.

The refutation of Nestorian teaching at the Council of Ephesus enabled Christian theology to get rid of the Christological division of the individual. An important achievement of the council was the proclamation of the theological concept that in human nature Christ as the Word accepted the fullness of mankind. The Catholic doctrine of the role of the Virgin Mary in the work of salvation and her maternal intercession, which leads to the acceptance by all people of Jesus as their Savior and the formation of the image of the Son of God in believers, is analyzed. It has been proved that for the believers of the Roman Catholic Church, Mary is not only the Mother, but also the example of the Christian life and the image of the whole Church.

Key words: Mariology, the Virgin Mary, Christology, Soteriology, apocrypha, Gospel, religious dispute.

Christian culture, as a completely spiritual tradition, removes the divine status of a woman, but leaves behind her the most important functions of the birth of the living God Jesus Christ and protection of the whole human race. Most researchers consider that the cult of the Virgin Mary was formed during long discussions between Christian theologians, which contributed to the official recognition of the Virgin Mary. The most common cult of the Virgin became in Catholicism, where she is called the Madonna. The Roman Catholic Church developed the doctrine of the Virgin Mary Mariology and adopted dogmas about the Incarnation, the Immaculate Conception, the Assumption and the Ascension of the Virgin Mary. The idea of the birth of Jesus Christ from the Virgin Mary, meanwhile, plays a very important role in the ontology and anthropology of Christianity. The atoning sacrifice of Jesus Christ removes original sin from man and radically changes his status. The woman who caused the fall of the human race becomes

(C) G. Rozbytska, 2020 
the way to its salvation. By becoming the Chosen Mother of the Savior of the world, she gained one and universal glory.

In this context, the Virgin Mary issues become important, the main provisions of which have not only theoretical but also practical application in variations of confessional systems. Therefore, research in the philosophical and religious context and the study of all theological aspects is a necessity due to time. In view of this, the subject of our study will be the history of the formation of the dogma of the Virgin, reflected in the New Testament and apocryphal literature. Analyzing the transformation of Catholic dogmas to understand the figure of the Virgin Mary is important today. Therefore, formulating certain conclusions and summarizing the theoretical provisions of our study, we will use historical materials and modern developments in the field of theology and in the field of philosophical sciences.

The article analyzes the main trends in the study of the formation of the Virgin Mary of Christian patristic on the basis of the works of theologians L. Berkhov, O. Men, L. Pisarev, M. Posnov, which focused mainly on the historical context of the process of Mariology. However, in the works of these researchers, the issue of the Virgin did not take its rightful place, although it is the semantic center of Christian doctrine. Analyzing the literature of the study, we note that mainly theologians deal with the problem of Mariology, which indicates the lack of coverage of this issue in modern religious studies.

In our analysis, we will proceed from the fact that the study of the Holy Father's literature requires two tasks: to trace the sources and development of the ideas of the Mother of God and to systematize the main content of the Mariological doctrine. The difficulty of this task is the lack of a unified methodological approach. It is important to note that most researchers in analyzing the figure of the Virgin Mary of the Apostolic Fathers prefer the historical development of views or use the analysis of the semantics of the Virgin terminology, building on their historical line. The use of these approaches separately leads to the accumulation of all the problems of New Testament theology within a particular topic.

The role and place of the Virgin Mary in the history of mankind and the birth of Jesus Christ is reflected not only in the Holy Scriptures, but in other sources of the period of early Christianity. These, first, include oral traditions, which were recorded in the works of other contemporaries of early Christian history, disciples of the apostles and the first Christian hierarchs, forming the basis of apocryphal literature. Of these works, a special place for our study is occupied by the Proto-Gospel of James, which is not included in the biblical canon, but contains the genealogy of the Virgin Mary and explains the discussion of the history of New Testament events. The work itself was translated into various languages in the early Middle Ages, including Syriac, Coptic, and Armenian, and its early text, "The Birth of Mary, The Revelation of Jacob", was found in 1958 in Egypt on a papyrus named after the researcher Bodmer.

The story of the event of the Annunciation is told on behalf of the son of Joseph and the brother of Jesus James. Thus, the pages of the apocryphal text cover the birth of Jesus, which contained the idea of the Immaculate Conception, causing controversy with those who did not acknowledge the birth of Jesus Christ by the Holy Spirit. Some researchers suggest that this work belongs to one author who tries to build the story with various sources not personally related to the Virgin Mary and the testimonies he borrowed from the Gospels of Matthew and Luke.

In the context of our study, we consider it necessary to shed light on the biography of the Virgin Mary on the basis of which the dogma of the Mother of God in Catholicism about the Incarnation and the Immaculate Conception were formulated. As is known from the Protestant Gospel of James, the parents of the future mother of Jesus Christ, Anna and Joachim, were respectable people because her father belonged to a cohort of priests of the Jerusalem temple. 
Mary's mother Anna was a rich and righteous woman, but childless. Her husband did not want to leave his wife, despite the constant humiliation they suffered from the public, because this state of affairs was considered a sign of sin or God's punishment [1, p. 20-23]. Anna suffered from the pressure on her family, so she prayed tirelessly to the Lord with hope and humility, asking for His blessing, and received a great reward by becoming parents. While in different places, Anna and Joachim received a revelation from an angel that God had heard their prayer and would bless them as a child, despite the couple's advanced age. After the birth of her daughter Mary, her parents sacrificed her to the god and brought her to the Temple in Jerusalem. This event is rooted in the Christian tradition and is celebrated as the Entry into the Church of the Virgin Mary, occupying a special place in a number of festive events of the Christian church [2, p. 41].

Having fulfilled their purpose on earth, Mary's parents left her in the care of the Temple. The Gospel of James states that as a teenager, Mary lost her parents, and the rectors of the Temple in Jerusalem sought a righteous man to care for her. The apocryphal text describes how a call was made to men of the house of David, who were unmarried or widowed, to come to the temple in Jerusalem. It was then that Joseph's staff flourished and thus he was chosen as a widower as Mary's guardian, despite his advanced age. This decision was unanimously adopted by the council of elders of the Temple [3, p. 105]. Note that the Proto-Gospel of James describes events that are not reflected in the canonical texts. In particular, when Mary was already expecting a child, she and Joseph were called back to the Temple as those who had not kept their vows, even though they had been engaged for a year. However, what exactly the promise was broken in the text is not told.

Instead, the Gospel of Luke contains a passage that suggests that while in hope, Mary and Joseph were not yet married: "And Mary said unto the angel: How shall this be, seeing I know not a man?" (Luke 1:34). In our opinion, the very neglect of the Nazarene tradition by Mary and Joseph led to the indignation of the clergy about their breach of the vow of marriage. The Old Testament book of Numbers describes in detail the cult of the Nazarenes among men and women. It is known that the Nazarenes gave eternal and temporary promises, but they concerned mainly men who went to preach later. Instead, women lived mostly at the Temple and, like men, performed the following duties: "When a man or woman decides to make a vow, he watches to dedicate himself to the Lord" (Numbers 6:2). Samson and his father Manoah followed the traditions of Nazareth: "For, behold, thou shalt conceive, and bring forth a son, and the razor shall not touch his head: for the child shall be a Nazarite from the womb, and he shall begin to save Israel out of the hand of the Philistines" (Judges 13:5). As well as John the Baptist: "And the child grew, and waxed strong in spirit, and was in the deserts till the day that he appeared unto Israel" (Luke 1:80).

We believe that Mary, being in the temple, made a vow of Nazareth, which led to the search for a guardian for her from a cohort of faithful and righteous men who would help her to keep her voluntary commitments. Hence the requirement of the clergy for Mary and Joseph to appear at the Temple when it became known about the future motherhood, which, according to the clergy, took place contrary to the promise of Nazareth.

The Gospel of Luke most fully describes the event of the Annunciation, which in Catholicism formulated the dogma of the Incarnation. According to the evangelist, Mary, being betrothed to the widow Joseph, received word from an angel that she was blessed among women (Luke 1:28), who would soon give birth to the Son of God, Jesus. "The Holy Spirit will be poured out on you, and the power of the Most High will overwhelm you, therefore the Holy One who is born will be the Son of God!" (Luke 1:35). It was a difficult circumstance for Mary to explain to Joseph her mission of motherhood, because in those days, a woman who committed adultery 
was stoned, which meant a slow death. In such a difficult situation, Mary did not choose her will for herself, but did the will of God, although she did not know for sure what would await her in the future.

Although the Catholic Church emphasizes the importance of the Virgin Mary's voluntary consent to accept God's will at the time of the Annunciation, this agreement is in fact a formality. Mary was destined to become the Mother of the Son of God before birth and was miraculously prepared and doomed. She is deprived of original sin and protected by God's grace from personal sin; she became a humble servant of God not through a conscious choice of such service, but in a natural way, because this obedience and holiness already constituted her essence. Thus, Mary decided, contrary to all trials, to do not her own will, but God's. All this is also a manifestation of the existing notion of grace in Catholicism, which is considered by Catholic theology as a special gift of the Lord, a certain manifestation and salvation of him as first of all the work of the Lord. It was for the fulfillment of God's prophecy that the Roman Catholic Church called her "New Eve" [4, p. 41].

It is important to note that according to Catholic theology, Mary not only fulfilled the divine will, but also opened the way to fulfill God's promise by interfering with Satan's plans, taking responsibility for the birth of the Son of God. Evidence of this is the fragmentary passages from the Gospels and the Apocrypha in which it is mentioned that Joseph did not believe Mary at first, but later began to help her: "And Joseph her husband, being righteous, and not willing to glorify her, would secretly release her. And when he thought on these things, behold, an angel of the Lord appeared unto him in a dream, saying: Joseph, son of David, do not be afraid to receive Mary your wife, for in her you will receive the Holy Spirit" (Matthew 1:19-20). It is in Mary's special way of becoming the Mother of the Son of God that Catholics see the joint efforts of God and men, namely Mary and Joseph, to fulfill the Lord's promise to give birth to the Son of God. From the point of view of Christian teaching, they did everything in their power to make Jesus grow and later fulfill his purpose on Earth. It is clear from the Gospels that Mary had to raise her son on her own, but in spite of everything she believed in God's promise and helped Him.

The cult of the Virgin Mary was not immediately established and sufficiently developed in Christianity. The first mention of the Virgin Mary is found in the New Testament book "Revelation of John the Theologian". In it, the Virgin Mary is depicted as a cosmic creature with eagle wings, surrounded by sunlight, on her head a wreath of twelve stars. It is not told about the earthly life of the Mother of God in later Christian works.

More than three centuries passed from the first mention of the Christian Mother of God in the second half of the first century to the formation of her cult in Christianity. During this time, Christian theologians endowed the Virgin Mary with increasingly unearthly traits. However, the tendency to glorify Mary was opposed by some Christian writers. In particular, Tertullian believed that Mary, after giving birth to Jesus, lived a married life with her husband Joseph. Origen claimed that Jesus had brothers and sisters. Even John Chrysostom and Augustine the Blessed were not convinced of Mary's virginity, that is, they questioned the doctrine of her immaculate conception for the rest of her life.

In the "Panarion" of Epiphanius, Bishop of Salamis, we are talking about two views of the Mother of God. Thus, anti-decomerians opposed the veneration of the Virgin Mary as a divine person. The Colliridians, on the other hand, adored Mary and worshiped her as the "queen of heaven".

However, in the everyday minds of believers, the teachings of the Roman Catholic Church about the immaculate conception of Mary are often identified with the dogma of the immaculate conception of Jesus Christ. As rightly remarks V. Lossky: "The first of these teachings, repre- 
senting the innovations of Roman Catholicism, concerns the birth of the Blessed Virgin herself. While the second, the common theology treasure of the Christian faith, concerns the Nativity of our Lord Jesus Christ, who "for us men and for our salvation came down from heaven, and was incarnate of the Holy Spirit and of the Virgin Mary, and became man"' [5, p. 120]. This doctrine was officially approved for the Roman diocese in the 15th century and in the 18th century for the entire Roman Catholic Church. However, the most important for the spread of the new doctrine was the proclamation by Pope Pius IX on December 8, 1854, the dogma of the Immaculate Conception of Mary. In the bull "Ineffabilis Deus" the Pope wrote that the Blessed Virgin Mary from the first moment of her conception was saved from original sin. According to Catholic theologians, the preservation of Mary from original sin also means for her freedom from all the consequences of this $\sin$ in the moral order, that is, freedom from the propensity to sin.

We note that some theologians and scientists consider it quite reasonable miraculous conception from the standpoint of modern discoveries in the field of universe science [6]. However, the final formation of the cult of the Virgin Mary took place during the Ecumenical Councils, which laid the fundamental foundations of Christianity in Trinitarian teaching, Christological theology and Mariology. Given that the Second Ecumenical (I Constantinople) Council of 381 could not put an end to Christological discussions, asserting the substantial identity of the second Person to the Trinity to the first Person, the question of the union of the divine and human nature of Christ remained open.

The first to attempt to reveal this aspect of Christology at the heart of his theological system was the bishop Apollinaris of Laodicea. The vast majority of researchers point to the extremely high level of theological education and natural abilities of the thinker, who "raised many theological issues and discussed them with completeness, consistency and perseverance" [7, p. 372]. Thus, it is with the name of Apollinaris that the process of shifting the epicenter of theological thought from the field of theology to oeconomy is connected.

Fragments of the works that have come down to us give reason for some researchers to believe that Apollinaris was a follower of the Origen theory of the re-existence of souls. Apollinaris' Christology is based on the idea of unity, which he called "divine union". He was convinced that in Christ it is impossible to distinguish two persons or two beings; He is one nature of God. "The existence of two minds in one person is as impossible metaphysically as the physical existence of two bodies in one space" [8, p. 187].

The uncompromising critics of Apollinaris were the Antiochians, who were the first to question his Christological doctrine as incompatible with the teachings of the Antioch school. Antioch theologians believed that true human nature is inconceivable without its freedom, which is absent in the abstract essence propagated by Apollinaris. Note that, arguing with the followers of Arian doctrine, Apollinaris in the Christological concept came to similar conclusions. However, the consonance of Christological models can be called conditional. The teachings of Apollinaris were a prerequisite for the emergence of Monophysitism as a Christological current of Christianity, the basis of the study of which was the doctrine of the one divine nature of Jesus Christ, not double - Divine and human.

The dogmatic basis for the emergence of the Nestorian current was a divergent interpretation of the concept of "Virgin Mary" as a component of Christian doctrine and Christology. "We call the Blessed Virgin the Mother of God because our Logos and Lord were born of Her in human essence. This being of Jesus Christ from the very moment of His Incarnation became part of the incarnation of His Person. Therefore, the state of His conception in the womb of the Virgin, birth, childhood and activity belong to the One who is the true God in the flesh. Thus, despite the fact that the Son of God took from the Holy Virgin not a Divine, but a human being, she nev- 
ertheless gave birth to God in the flesh, so she is the Mother of God, without any inconsistency with the concept of Deity" [9, p. 294].

During discussions, theologians often appeal to the term "Virgin Mary" and the concept of "unity", which express the essence of Christian triadology. Comparing these concepts, researchers note that the word "single" was mainly used in theological environment, not widely used among believers, instead, the term "Virgin" became an expression of the faith of ordinary parishioners [9, p. 296-297]. The word "Mother of God" became part of the Holy Tradition, because "all the Fathers and Teachers of the Church, when they mentioned the Blessed Virgin, directly called Her the Mother of God, or affirmed the birth of God from Her" [10, p. 151-152].

After the proclamation of Nestorius by the Patriarch of Constantinople, a discussion began in his entourage regarding the use of the titles of the Virgin Mary. Commenting on this, he noted for the first time that the correspondence of the definition of the Virgin to the Virgin Mary in theology would be highly questionable. For the moderation of the wording of the title, Nestorius proposed to use the term "gave birth to a man". However, in order to convey the mystery of the Virgin Mary's motherhood, he considered the term "gave birth to Christ" to be the most appropriate definition, the use of which would not raise controversial issues. Nestorius confirmed his position in a letter to Pope Calestine, suspecting the parties to the conflict in the spread of Arian and Apollinarian ideas [11, p. 199]. In this message, Nestorius not only denies the use of the word "Virgin Mary", but also questions the two births of the God-man and the doctrine of deification.

This position of the Patriarch of Constantinople prompted protests from the church clergy, and the discussion quickly shifted from the Mariological to the Christological plane. Thus, Nestorius' denial of the use of the word "Virgin Mary" led to the formation of his own Christological concept and dogmatic teaching.

However, the next epistle to John of Antioch contains evidence that Nestorius used the term "Virgin Mary" with caution, trying to avoid Manichaean and Apollinarian statements. He continued to prove his position that "God has no mother and therefore Mary gave birth to a man, not God. He could not suffer, die and be buried" [12, p. 167]. Nestorius asserted that in the definition of Mary as the Virgin Mary is hidden the Arian doctrine, when the Son is a creature, or the Apollinarian idea of the incompleteness of human nature. Nestorius also saw the danger that the use of the term "gave birth to Christ" could lead to the recognition of the teachings of Arius. Thus, the texts of the sources confirm the conclusions of M. Anastos and A. de Alli, according to which Nestorius was wary of the term "Virgin Mary" and criticized the idea of the birth of the Logos from Mary through polemics with Manichaeism, Apollinarianism and Arianism.

By questioning the doctrine of deification, Nestorius finally dissociated himself from the orthodox understanding of Christology, for which "the natural consequence of the hypostatic union of the two beings in Christ is the deification of His human nature. The hypostatic union of the human being in Christ by the Logos was adored to the ultimate limit, without losing its character, limitations and humanity, but at the same time it did not cease to be human and remained within its limits" [11, p. 201]. According to researchers, Nestorius did not fully realize the essence of apophatic theology of the Church Fathers, understanding the Divine and human essence on one ontological level, not understanding that in Scripture the Divine nature is represented above human existence. Therefore, the real reason for denying the term "Virgin Mary" as the most correct for theology is Nestorius' refutation of the ancient Logos as the Subject of the birth of the Virgin Mary. Thus, the formation of the Christological concept of Nestorius took place when he, denying the principle of mutual exchange of properties, that the Subject of two births is the second Hypostasis of the Trinity. Nestorius agreed with the recognition of the Virgin as the beginning 
of human nature, but he did not recognize the hypostatic union with the Logos, as he followed a different scheme of the Subject of Christological predicates.

Thus, by denying the transfiguration of man as a result of communion with God, Nestorius distinguished between two subjects in Christ. However, realizing the weakness of his position and trying to justify previous statements that contradict Christian teaching, he states: "We keep the essences of God indivisible, considering them united by will. Therefore, we celebrate one will, one action and one domination as a manifestation of their equality. The Logos, having accepted a man whom He had predetermined, on the basis of His Divine authority, did not dissociate himself from it, foreseeing a special inner devotion" [11, p. 202]. This statement clearly traces the fundamental thesis of the ontological symmetry of the Divine and human essence in Christ.

Rebutting the principle of mutual exchange of properties, Nestorius uses common (Christ, God, Son) and proper (Logos and Jesus) names to define the Second and Third Persons of the Trinity [13, p. 78]. The birth of the Virgin Nestorius refers to the properties of human nature that cannot be transferred to the Logos. According to the Christological theory of the Patriarch of Constantinople, the combination of two natures in Christ leads to the recognition of two incarnations in Him and the denial of ontological unity. Therefore, the term "gave birth to Christ" Nestorius means the union of two natures in one Person of Christ [13, p. 80]. It is possible to call Mary the "Mother of Christ" because of the union of human and divine nature in Christ. According to Nestorius, the subject of birth from the Virgin is the Person who is not identical with the Logos.

Thus, the Christological formula of Nestorius contains "two natures - two incarnations two natural persons - one Person of unity". Confession of two incarnations is a direct consequence of the idea of independently existing nature, which is invariably needed by incarnations [13, p. 80-81]. For Nestorius, both incarnations of Christ are original, independently existing, because each of them forms a Person. It is this feature that allows us to define the Nestorian Christology as two-subject at the level of two incarnations and one-subject at the level of the Person of connection.

The role of the Virgin Mary in the work of salvation corresponds to how the theology of Catholicism determines the end of the world and the destiny of mankind. The eschatology of Catholicism is the expectation of the Last Judgment of God, which will take place according to all canonical rules, and therefore the saints play an important role. Among them, the Virgin Mary occupies an important place as the Intercessor and Mediator. No wonder many images of the Madonna are found in Catholic church art, which protects believers addressed to her with his cloak. Mary's maternal intercession leads to the acceptance by all people of Jesus as their Savior and the formation in believers of the image of the Son of God. For the Church, Mary is not only the Mother and intercessor, but also the model of the Christian life and the image of the whole Church.

The Catholic Church proclaims that Mary continues to fulfill her maternal task in Heaven, where she is with soul and body. The dogma proclaimed by Pope Pius XII about the Assumption of the Blessed Virgin Mary says that "the Immaculate Mother of God was taken with body and soul to the Glory of Heaven after the end of her earthly life". This dogma proclaims that Mary died in the company of the apostles and was laid to rest. When it was later opened, it turned out that it was empty. And then the apostles concluded that her body and soul had been taken to Heaven.

Thus, in Catholicism, unlike other Christian denominations, the dogma dogmas about the Incarnation, the Immaculate Conception, the Assumption and the Assumption of the Virgin Mary were formed, which complement the Christological teaching formed on the basis of Scripture and apocryphal literature. They affirm the Christian dogma of the divinity of Jesus Christ, explaining the existence in one person of divine and human nature and divine and human will. 


\section{References}

1. Окулов А.Ф. Апокрифы древних христиан. Исследование, тексты, комментарии. Москва : Мысль, 1989. 336 с.

2. Геник Л. Історія християнства : Католицизм. У 2-х т. Т. 1: Основні ідеї християнства. Навчальний посібник для студентів вищих навчальних закладів. Вид. 2-е доп. Івано-Франківськ : Тіповіт, 2012. 576 с.

3. Гречко І. Великий поділ християнства і його трагічні наслідки. Київська Церква. 2000. № 4. С. 104-107.

4. Катехизм Католицької Церкви : Компендіюм. Львів : Свічадо, 2008. 200 с.

5. Лосский В. Спор о софии. Статьи разных лет. М.: Издательство Свято-Владимирского Братства, 1996. 196 с.

6. Фурдуй Р. Швайдак Ю. Астральное зачатие. Прелесть тайны. Киев : Лыбидь, 1992. С. 105-130.

7. Поснов М. История Христианской Церкви (до разделения Церквей 1054 г.). Брюссель : Жизнь с Богом, 1964. 614 с.

8. Lietzmann H. Apollinaris von Laodicea und seine Schule: Texte und Untersuchungen. Tübingen : Mohr, 1904. XVI, 323 s.

9. Евагрий Схоластик. Церковная история: [в 6 кн.] : кн. 1-6; пер. с греч., вступ. ст., коммент и прилож. И.В. Кривушина. 2-е изд., испр. Санкт-Петербург : Изд-во Олега Абышко, 2006. 669.

10. Лебедев A. Вселенские соборы IV и V векав : обзор их догматической деятельности в связи с направлениями школ Александрийской и Антиохийской. 2-е изд., испр. и доп. Санкт-Петербург : Изд-во Олега Абышко, 2004. 320 с.

11. Соколовський О.Л. Христологія: еволюція доктрини : монографія. Житомир : Вид-во Євенок О.О., 2018. 472 с.

12. Соколовський О.Л. Ефеський собор у світлі христологічних дебатів. Гілея: науковий вісник. 2018. Випуск 131 (№ 4). С. 165-169.

13. Селезнев Н. Несторий и Церковь Востока. Москва : Путь, 2005. 111 с.

\section{ОСОБЛИВОСТІ ФОРМУВАННЯ БОГОРОДИЧНИХ ДОГМАТІВ У КАТОЛИЦИЗМІ}

\section{Галина Розбицька}

Житомирський державний університет імені Івана Франка, кафедра філософії та політологіі

вул. Велика Бердичівська, 40, 10008, м. Житомир, Україна

У статті проаналізовано формування культу Богородиці у християнстві. Доведено, що становлення культу Діви Марії відбулося в період Вселенських соборів, які заклали фундаментальні засади християнства у тринітарному вченні, христологічній теології та маріології. Обгрунтовано, що II Вселенський (I Константинопольський) собор, утверджуючи субстанційну тотожність Осіб Трійці, не зміг покласти кінець христологічним дискусіям у питанні з'єднання божественної та людської природи Христа, яке залишалося відкритим.

Виокремлено основні богородничі догмати в католицизмі, які доповнюють христологічне вчення, сформованого на основі новозавітної літератури. Визначено джерела формування уявлень про Пречисту Діву, які належать до періоду раннього християнства. Встановлено значення Ефеського собору, який заклав початок пошануванню Діви Марії, проголошуючи іï Богородицею. Доведена перевага в христологічних дебатах олександрійської катахетичної теології над антіохійською богословською школою. Сформульовано висновки й узагальнено теоретичні положення, що 
стосуються культу Пресвятої Богородиці, шляхом дослідження історичних матеріалів і сучасних розробок у галузі теології і філософських наук. Обгрунтовано, що христологічна концепція константинопольського патріарха Несторія призвела до визнання двох іпостасей у Христі і заперечення онтологічного єднання. Для Несторія обидві іпостасі Христа є самобутніми, самостійно існуючими, оскільки кожна з них утворює Особу.

Спростування несторіанського вчення на Ефеському соборі дало змогу християнському богослов'ю позбутися христологічного розділення особистості. Важливим здобутком собору стало проголошення богословської концепції, що в людській природі Христос як Слово прийняв повноту людства. Проаналізована католицьке вчення про роль Діви Марії у справі спасіння і її материнському заступництві, яке веде до прийняття всіма людьми Ісуса як свого Спасителя та формування у віруючих образу Божого Сина. Доведено, що для вірян Римо-католицької церкви Марія є не лише Матір'ю, а зразком християнського життя та образ усієї Церкви.

Ключові слова: маріологія, Богородиця, христологія, сотеріологія, апокрифи, Євангелія, релігійний диспут. 